\title{
Politics Does Matter: The Nigerian State and Oil (Resource) Curse
}

\author{
Omobolaji Ololade Olarinmoye*
}

\begin{abstract}
Conventional explanations of the resource curse, or the paradox of abundance, correlate resource abundance and bad economic policies, underdevelopment, poverty and conflict. Such a conclusion has become debatable and has encouraged analysts to develop conditional explanations that emphasize the role of the political rather than economic factors in the mechanisms underpinning the resource curse. Using the Inter-governmental Fiscal Relations system in Nigeria as an example, this paper argues that, while the policy choices of politicians determines how resource rents are utilized, the extent to which political institutions promote the use of rational and meritocratic criteria in allocating public sector resources and ensure accountability is what matters. This is of crucial importance in determining whether resource abundance will lead to resource curse.
\end{abstract}

\section{Résumé}

Les explications conventionnelles de la malédiction de la richesse ou du paradoxe de l'abondance font la liaison entre l'abondance de la ressource et la mauvaise politique économique, le sous-développement, la pauvreté et les conflits. Cette conclusion est trés discutée et a encouragé les observateurs à donner des explications conditionnelles qui pointent sur le rôle des facteurs politiques, plutôt qu'économiques, constituant les mécanismes de base de la malédiction de la richesse. En se basant sur le Système des relations fiscales inter-gouvernementales du Nigeria comme modèle, ce document soutient que même si les choix politiques des politiciens déterminent la façon dont les rentes émanant de la ressource sont utilisées, ce qui importe le plus, c'est de savoir dans quelle mesure les institutions politiques encouragent l'utilisation de critères rationnels basés sur le mérite dans le cadre de l'allocation des ressources publiques et assurer la transparence dans l'utilisation de ces ressources. Ceci est d'une importance capitale pour savoir si c'est l'abondance de la ressource qui entraîne la malédiction de la richesse.

* Programme Coordinator with the Council for the Development of Social Science Research in Africa, CODESRIA, Dakar. E-mail: ololade001@yahoo.com. 


\section{Introduction}

For most Nigerians, especially those living in the Niger-Delta, Nigeria's oil wealth is actually 'oil of poverty' (ANEEJ 2004) or a curse, because it has produced only poverty, underdevelopment and conflicts since its commercial exploitation began in the late 1950s. Such a conclusion is not aberrant as 'it is now almost conventional wisdom that (natural) resources are a curse for developing countries' (Robinson et al. 2005:2) with abundance of natural resources causing poor growth and raising the incidence, intensity and duration of conflicts.

The negative conclusions about the developmental role of resources is a far cry from earlier post World War hopes and the promise that resource endowment would 'lift' many countries out of poverty; as 'not only would resource exploitation generate fiscal revenues and jobs, but also the necessary investment capital for an economic take-off. Windfall resource revenues, in other words, should prove a bonanza' (Rosser 2006).

But 'for every Venezuela and Nigeria, there is a Norway or a Botswana' (Robinson et al. 2005:7). Research on 'paradox of plenty' has prompted, in recent times, a renewed interest in political factors as key explanatory variables, or as key components of the resource curse mechanism in developing countries. For example, it has been argued that 'poor economic growth is itself a political product, the consequence of what politicians do with resource rents' (Englebert 2000; Ron 2005:447) and of presence or absence of 'political institutions which promote the accountability of politicians' (Robinson 2005:6).

Thus, if resource booms create underdevelopment, it cannot be because 'they induce inefficiency in the rate at which they are extracted, but because politicians make policy mistakes (which) are in fact rational political strategies, in response to the incentives induced by resource rents' (Robinson et al. 2005:6).

As argued by Rosser,

Put differently, scholars have been asking the wrong question: rather than asking why natural resource wealth has fostered various political pathologies and in turn promoted poor development performance, they should have been asking what political and social factors enable some resource abundant countries to utilize their natural resources to promote development and prevent other resource abundant countries from doing the same (Rosser 2006:10).

It is such a reasoning that guides this paper, which attempts to re-interpret the 'paradox of abundance' thesis through a focus on the actors and institutions of the Inter-governmental Fiscal Relations (IGFR) system of the Nigerian state, the world's fifth largest producer of crude oil. 
IGFR deals with all 'fiscal transactions and coordination arrangements among the various tiers of government in a federation' (Musgrave and Musgrave 1989; Ekpo 2004:2). Its role is that of balancing fiscal responsibilities with revenue collection processes at the different levels of government within a federation and so is the mechanism by which it is expected that proper accountability in the use of resource rents will be achieved. A study of its functioning since the Nigerian independence provides an ideal context to examine the mechanisms linking natural resource endowments and their prices to development.

The paper is in three parts. The first reviews the theoretical debate on 'Resource Curse' or the 'Paradox of Abundance'; parts two and three present the various dimensions of a conditional explanation of resource curse based on the IGFR system in Nigeria, while the conclusion presents an assessment of two contending explanations about resource curse.

The central argument of the paper is that one of the reasons for Nigeria's underdevelopment can be imputed to the malfunctioning of the IGFR system. Therefore, an investigation of the functioning of the IGFR system in Nigeria will show that the 'oil curse' paradox needs to be understood as a political process.

\section{Resource Curse: Theoretical Debates}

Recent literature suggests that resource abundance can be conceived as a 'paradox of plenty' (Basedau 2005:8) because it does not produce the expected outcomes but creates problems such as poverty, economic decline and conflicts.

Natural resources, it is argued, generate a 'paradox of plenty because they create dependence and damage other tradable sectors and sources of economic growth and development such as human capital and the manufacturing sector' (Basedau 2005:10), stimulate unwise economic policies such as import substitution policy which prevent efficient and effective investments of rents and make the economy vulnerable to external shocks caused by declining terms of trade as natural resources exhibit lower income elasticities of demand than manufactured products.

Furthermore, their exploitation can lead to civil wars by making central governments weaker because, as Fearon and Laitin (2003:87) suggest; 'Oil exports may be relevant, not so much because they finance rebel groups but... because they mark relative state weakness at a given level of income. Similarly, they can lead to separatist conflicts by giving resource-rich regions an economic incentive to become independent (Le Billon 2001; Collier and Hoeffler 2002; Ross 2003) and encourage looting as a mean of funding insurgencies, as insurgents often raise start-up funds by looting and selling natural resources (Ross 2005:5). Therefore, 'resource wealth leads to a 
myopia among policy makers and weakens state accountability to the citizenry' (Weinstein 2005:599).

Backed as it is by empirical evidence, namely aggregate evidence linking resource rents to coups, incidence of armed conflict and the incidence and duration of conflicts (Dunning 2005:451), the 'paradox of plenty' thesis has to contend with the fact that:

While the studies ... provide evidence that natural resource abundance - or at least an abundance of particular types of natural resources - and various development outcomes are correlated with one another, they do not prove that the former causes the latter. Those arguing in favour of the notion of a resource curse have merely inferred causality from the evidence of correlation. However, the direction of causation may in fact run the other way (Rosser 2006:12).

Thus 'tasked with explaining the large variations in outcomes among natural resource exporters' (Dunning 2005:451), scholars have sought to address the issue of variation in the development profile of resource abundant states by focusing on conditional explanations that give prominence to political factors, such as the state's strength, and the capacity and role of actors (particularly politicians) and institutions in the management of resource rents.

Fearon, for example, argues that much of the resource-war association is explained by oil exports which trigger conflict through political - not economic - mechanisms as it creates weak extractive apparatuses. The low political capabilities of rentier states then create opportunity for rebellion (Fearon 2005:487). For Dunning, the paradox of resource abundance is dependent on attempts by rulers of resource rich countries, in search of regime stability, to either undermine or encourage local attempts at economic diversification and growth (Dunning 2005:452-453). Snyder and Bhavnani, on the other hand, suggest that a commodity's physical characteristics, together with the manner in which it is extracted helps determine state capacity in resource rich countries (Snyder and Bhavnani 2005:564-566).

For Robinson et al. (2005), resource curse is the result of policy mistakes that are in fact rational political strategies developed by politician-entrepreneurs as they respond to the incentives induced by resource rents and absence or malfunctioning of political institutions. These promote the accountability of politicians generally, develop state institutions away from patrimonial practices towards the use of rational and meritocratic criteria in allocating public sector resources. In summation, conditional analysis that favour political factors primarily in the form of political actors and state institutions provide the best picture of the mechanism linking natural resource endowments and their prices to development. 


\section{Institutions Matter: IGFR and the Politics of Resource Curse in Nigeria}

Nigeria is a federation; a political arrangement that has been adopted to strike a balance between unity and diversity, since it allows 'the component units of a political organization to participate in sharing powers and functions in a cooperative manner in the face of the combined forces of ethnic pluralism and cultural diversity' (Aiyede 2004; Tamuno 1998). In economic terms, a federation is a system of government where revenue and expenditure functions are divided among the various tiers of government.

A federal institutional arrangement involves the decentralization of the fiscal system or Fiscal Federalism (Okigbo 1965). It means that finance is the engine of the federal system with its proper functioning being a direct result of a stable system of revenue allocation between the various levels of government. IGFR refers to the fiscal transactions and coordination arrangements among the various tiers of government within a federation (Musgrave and Musgrave 1989). Its primary concern, balancing fiscal responsibilities with revenue collection processes at the different levels of government within a federation, makes IGFR the key political institution involved in ensuring accountability in the use of resource rents within the Nigerian federation.

The presence of political institutions to maintain accountability does not translate into efficient utilization of resource rents or the absence of a resource curse, even though Robinson et al. rightly suggest that countries with institutions that promote accountability and state competence will tend to benefit from resource booms since these institutions ameliorate the perverse political incentives that such booms create and countries without such institutions however may suffer from a resource curse (Robinson 2005:7).

According to Sachs and Warner (1999), what matters is the 'Institutional Quality Index', 'the quality of the institutions', the extent to which such institutions promote the use of rational and meritocratic criteria in allocating public sector resources. The index ranks Botswana, Chile, Malaysia and Thailand ahead of Algeria, Ecuador, Mexico, Nigeria, Trinidad and Tobago, Venezuela and Zambia in terms of institutional quality. Botswana, Chile, Malaysia and Thailand all happen to be resource rich countries that have succeeded in avoiding the paradox of plenty, whereas Nigeria, Trinidad and Tobago, Venezuela and Zambia all suffer from the resource curse.

A major imbalance in the assignment of tax raising powers between its units (which translates into greater concentration of tax raising powers in the hands of the federal government and the dependence of the lower governments on federal government funding, leading to frustration and tensions in inter-governmental relations between the units of the federation) 
is the key expression of the low institutional quality index of Nigeria's IGFR system (Anyawu 1995; Alm and Boex 2002; Bird and Smar 2001; Ehtishan and Singh 2003; Ekpo 2004; Mbanefoh 1986, 1989).

The problems of the IGFR system in Nigeria result from the inefficiency of four important sub-components: The Executive (federal, state and local government), the Legislature (federal, state and local government), the Judiciary (state and federal) and the various ad-hoc and permanent fiscal commissions. Only the Executive component is in charge of policy-making, while the other three perform oversight roles to varying degrees. Section 162(1) of the 1999 constitution indeed

'provides for a common pool of financial revenue the federation Account into which is paid all monies to be distributed among the federal, states and local governments councils in each state on such terms as may be fixed by the National Assembly' (FRN 1999) (author's emphasis).

Section 162(2) highlights that:

The President upon receipt of advice from the Revenue Mobilization Allocation and Fiscal Commission (RMAFC), shall table before the National Assembly proposals for revenue allocation from the Federation Account and in determining the formula, the National Assembly shall take into account, the allocation principles, especially those of population, equality of states, internal revenue generation, land mass, terrain, as well as population density. Provided that the principles of derivation shall be constantly reflected in any approved formula as being not less than 13 per cent of the revenue accruing to the Federation Account directly from any other resource (FRN 1999).

Due to a number of reasons which will be discussed, the Legislature, the Judiciary and the Fiscal Commissions have not been able to conduct effective checks on the Executive and the decisions made as to how to distribute resource rents. In other words, they have not been able to prevent the perverse policy choices (increase in size of public service, neo-patrimonial corrupt practices) made by politicians who have constituted the building blocks of resource curse.

At the core of the IGFR system is the budget. It represents 'the key instrument for maintaining accountability in government finances or use of resource rents. It sets spending limits and revenue patterns for all sectors of government and therefore affects income distribution and social activities and impacts on overall levels of economic activity' (Aiyede and Isumonah 2002:3).

The Executive is in charge of preparing the budget, while the Legislature authorizes the Executive to raise and spend money, and exercises oversight over the activities of the Executive. In situations where the legislature cannot 
maintain its oversight function, the budget becomes a tool for mismanaging resource rents by the executive.

The process of budget-making in Nigeria has, since independence, been a chaotic one. Under civilian rule, it has experienced 'hold-ups' due to differences in specific powers of the legislature over the budget. The maximalist view argues that the powers of legislature oversight should not be restricted in any way, while the minimalist view, favoured by the executive, argues for a minimal role of the legislature in the budgeting process (IPU 1986). The result has been a totally inefficient budgeting process with delays occurring in the preparation and passing of budgets and with different groups engaging in political brinkmanship. In such a situation, it is the Executive that has always triumphed because of:

(a) Constitutional provisions such as Section 82 of the constitution, which states that,

If the appropriation bill in respect of any financial year has not been passed into law by the beginning of the financial year, the president may authorize withdrawals of moneys from the Consolidated Revenue Fund of the federation for the purpose of meeting expenditure necessary to carry on the services of the government of the federation for a period of six months or until the coming into operation of the appropriation act; whichever is earlier' (FRN 1999).

(b) Decrees such as Decree 53 of 1991 that have been applied by the Executive to by-pass the Legislature. The case for legislative oversight and accountability of the Executive was worsened by the fact that Nigeria has been governed by military forces since its independence. Military rule worsened the Executive's recklessness because of their institutional characteristics, often opposed to an equal participation among all the usual actors of policy-making. As pointed out by Claude Ake,

The military and democracy are in dialectical opposition. The military is a taut chain of command; democracy is a benign anarchy of diversity. Democracy presupposes human sociability; the military presupposes its total absence, the inhuman extremity of killing the opposition. The military demands submission, democracy enjoins participation; one is a tool of violence, the other a means of consensus building for peaceful co-existence (Ake 1995).

Thus, though the military regime created a vast IGFR structure, the influence of its norms (command, hierarchy and order) on the federal system of government denied the state's autonomy and voluntary participation in revenue allocation and decision-making processes. The 'give and take' that ought to characterize decision-making in a federal system were stifled, as the military regime ensured that no institution could successfully overlook its role. 
Furthermore, the control that was supposed to be provided by the Judiciary was nullified by the regime through a suspension of wide sections of the constitution, the use of decrees and the use of ouster clauses that placed the actions of the military Executive beyond the jurisdiction of the courts.

The other institution able to hold the military Executive to some degree of accountability was the Fiscal Commissions, mandated to study comprehensively and make recommendations regarding the administrative and financial procedure to be adopted by the Executive. It, however, had its recommendations ignored, rejected or modified in order to suit the Executives' requirements.

The federal government indeed rejected the report of the Dina Fiscal Commission of 1968 and enacted the Decree 13 of 1970 that allocated the bulk of federally collected revenue to the federal government (Emenuga 1993:85); Decree No. 9 of 1971 that transferred the rents and royalties of offshore petroleum mines from the states to the federal government, and Decrees No. 6 and 7 of 1975; that established firmly the position of the Executive in the driving seat of IGFR in Nigeria (Oyediran and Olagunju 1984:199-202).

The report of the Aboyade Technical Committee on Revenue Allocation of 1977, which recommended a clear division in tax jurisdiction in order to provide all tiers of government with a tax base, was rejected by the Constituent Assembly, a coalition of politicians, officially because it was too technical but probably because its recommendations were creating an effective control mechanism on the use of resource rents by the Executive (Mbanefoh and Egwaikhide 1998; Ekpo 2004:18-20).

The 1981 Okigbo Commission recommended that the Federation Account be shared among the tiers of government on the basis of 53 per cent for the federal government; 30 per cent for the state government; 10 per cent for the local government and 7 per cent for special funds. It was, however, revised as the federal executive jerked its share upwards by 2 per cent to 55 per cent and reduced the local government's share by 2 per cent. The share of the state's and special funds remained unchanged. The Supreme Court, on 2 October 1981 declared the new formula as unconstitutional and demanded a new formula be elaborated. The modification passed through the National Assembly in 1981, as Revenue Act of 1981, and became operational in 1982 (Mbanefoh G.F 1989; Ekpo 2004:21-22).

The Revenue Mobilization Allocation and Fiscal Commission (RMAFC) was the first permanent revenue allocation commission established by the military government, through Decree 49 of 1989. It recommended the vertical allocation formula to be: federal government 47 per cent, state government 30 per cent, local government 15 per cent, and special funds 8 per cent. For horizontal allocation it recommended: equality of states 40 per cent, population 
30 per cent, internal revenue effort - 20 per cent, social development factor 10 per cent. The military government accepted its recommendations but raised its own share by 3 per cent and reduced the special funds by a similar percentage (Akpan 2004:22-23).

In January 1991, after the federal government promulgated Decree 3 of 1991, which transferred the responsibility for primary education (formerly shared by the three tiers of government) to the local governments, the RMAFC recommended an allocation of 5 per cent of the Federation Account to local governments for funding primary education. The military government decided to take the 5 per cent from the states' share of Federation Account, thus giving rise to a formula of: federal government 50 per cent, state governments 25 per cent, local governments 20 per cent and special funds 5 per cent. Six months later, the military government made another adjustment in the revenue sharing formula, giving the federal government 48.5 per cent, the state government 24 per cent, local government 20 per cent and special funds 7.5 per cent. The new formula lasted till the end of the military rule on 29 May 1999 (Akindele and Olaopa 2002; Ekpo 2004:22-23).

The recommendation of the Revenue Commissions strengthened the Executive's fiscal recklessness through the revenue allocation formulas, especially the horizontal revenue formulas they recommended, because they emphasized revenue sharing (Equality, Population, Land Mass and Terrain, Social Development Factors and Internal Revenue Effort) rather than revenue generation, and stimulated a culture of consumption that encouraged executive fiscal recklessness at all tiers of government (Uche and Uche 2004).

\section{Politics Matter: Politicians and Perverse use of Resource Rents}

As a result, the Executive dominated. The IGFR system provides an environment for the initiation of perverse policy choices by the Executive, which in turn produced the resource curse. In other words, the institutional apparatus created by government left politicians free in their decisions on how to spend resource rents and allowed them to saddle the system with policy choices that could be perceived as 'anti-developmental' but were commonly portrayed as rational and efficient.

The key to politicians' view of 'rational efficient use of resource rents' lies in understanding the politicians' worldview. The major objective of the politician is the acquisition of political power defined as 'the ability to systematically influence state decision-making processes’ (Lacam 1988). Political power thus involves 'the conquest of and conservation of one or several . . . centres of decision-making’ (Lacam 1988:25). In conquering and conserving control over decision-making, the politician is confronted with a number of constraints in the form of regulatory rules-electoral laws 
political finance laws (Ndubisi 2004) and contextual variables-cost of financing electoral campaigns (Garraud 1999; Briquet 1999), all of which can hinder his quest for and conservation of political power. Politics consequently appears as a matter of risk management, the successful politician being one who successfully overcomes, personally or thanks to the assistance of external agent(s), the constraints that threaten his political career.

A key to overcome the constraints of the acquisition of political power is patronage 'the way in which the politician distributes public jobs or special favours in exchange for electoral support' (Robinson 2005:4). The politician relies on his access to the state to accumulate economic resources, usually through corrupt practices. Some of these resources are then invested in economic enterprises while some are distributed to his clients as symbolic capital. This creates political supports that legitimise the access of the Executive to the state and its resources.

The redistribution 'art' is central to the legitimizing and accumulation of political capital that permits the continued access to state resources. The elite is known for excelling in the art of redistribution. Political mobilization in Africa is therefore an exercise in the art of redistribution, dominated by the elite (Daloz 1999, 2002, 2003; Ugochukwu 2004; Olarinmoye 2004; Joshi 2002). While the politician considers patronage as an efficient application of resource rents (it enables him to achieve re-election and hold on to political power) from a developmental perspective, patronage is perverse because it involves diversion of scarce resources towards satisfying private interests.

Patronage encourages the politician to divert resource rents in order to finance import-substitution policies associated with projects that are economically dubious but attractive to politicians. The diversion of scarce resources to private ends, and the failure to establish vital inter-sectoral transfers necessary for broad-based economic development, increase the overt reliance of the state on a single source of revenue. This renders it vulnerable to external shocks caused by the possible declining terms of trade in natural resources that exhibit lower income elasticities of demand than manufactured products.

The legitimacy of the politicians, and by extension of the state, is very shaky as the electoral support upon which it is based is dependent on a continued flow of resources from the state. In case the flow of resources is threatened, the political system breaks down. As patronage is a selective activity benefiting specific groups, those excluded are pushed to use violence to demand for and access their own share of the rents. In the case of the Nigerian Niger-Delta conflict, those excluded come from the resourceproducing region. The exclusionary use of resource rents can therefore encourage separatist conflicts. The funding of such conflicts can be made 
through looting, as insurgents seek to raise start-up funds by looting and selling natural resources.

\section{Conclusion}

Conventional explanations of resource curse or paradox of abundance correlate resource abundance and bad economic policies, underdevelopment, poverty and conflict because 'resource wealth leads to a myopia among policy makers and weakens state accountability to the citizenry' (Weinstein 2005:599). Such a conclusion, in the light of the presence alongside "cursed states" of successful resource abundant states has become debatable and has encouraged analysts to develop conditional explanations that emphasize the role of the political rather than economic factors in the mechanism of resource curse.

Specifically, this paper suggests that two key political factors best help to explain the resource curse in Nigeria: the political actors (politicians), their ethos/worldview and how they influence the decisions and policies made concerning the use of resource rents and political institutions that promote the accountability of politicians, and the use of rational and meritocratic criteria in allocating public sector resources.

While policies determine how resource rents are utilized, it is 'institutional quality', the extent to which such institutions promote the use of rational and meritocratic criteria in allocating public sector resources and ensure accountability that matters and is of crucial importance in determining whether resource abundance will lead to resource curse.

This argument is particularly relevant in the context of the Nigerian case developed in the paper, which shows how the IGFR failed to institute quality oversight over the activities of politicians. It also illustrates how such politicians, motivated by the desire to conquer and conserve one or several centres of decision-making, in the absence of checks and balances within IGFR system, have been deploying resource rents to serve patronage purposes.

The deployment of resource rents for patronage purposes constitutes a perverse policy choice from a developmental point of view. The Nigerian case shows that a conditional explanation of resource curse, which emphasizes political factors, does not imply that economic factors are not as important, but argues that the economic decisions of states are political products. Hence, a better understanding of the resource curse emerges from a study of the institutions and politicians entrusted with the responsibility of overseeing oil rents. 


\section{Bibliography}

African Network for Environment and Economic Justice (ANEEJ), 2004, Oil of Poverty in the Niger-Delta, Port-Harcourt.

Aiyede, E. R. and Adefemi Isumonah, V., 2002, Towards Democratic Consolidation: Executive-Legislative Relations and the Budget Process in Nigeria, Development Policy Center Research Report, No. 52, 28pp.

Akindele, S.T. and Olaopa, 2002, Fiscal Federalism and Local Government Finance in Nigeria, UNPAN document.

Alm, J. and Boex, J., 2002, ‘An Overview of Intergovernmental Fiscal Relations and Sub-national Finance in Nigeria', International Studies Program Working Papers 02-1.

Amuwo, Kunle et al., eds., 1998, Federalism and Political Restructuring in Nigeria, Ibadan: Spectrum Books.

Anyawu, John C., 1995, 'Revenue Allocation and Stable Fiscal Federalism in Nigeria’, Journal of Economic Management, Vol. 2 No. 2, October.

Bahl, R. and Wallace,S., Intergovernmental Transfers: The Vertical Sharing Dimension, Andrew Young School of Policy Studies, Atlanta.

Basedau, M., 2005, 'Context Matters-Rethinking the Resource Curse in SubSaharan Africa', Working Paper, No. 1, Institute of African Affairs, German Overseas Institute.

Bird, R. M. and Smart, M., 2001, Intergovernmental Fiscal Transfers: Some Lessons from International Experience, Hilosubashi University, Tokyo.

Briquet, J-L., 1999, 'Italie: Un Système de Pouvoir en procès', Critique Internationale, No. 3, Printemps.

Collier, P. and Hoeffler, Anke, 2002, 'On the Incidence of Civil War in Africa', Journal of Conflict Resolution, 46(1): 13-28.

Daloz, J-P., 2002, 'Cultural Heritage and Enduring Mentalities: Reflections on Political Representation and Accountability', Conference on Culture, Democracy and Development, Monte Verita, Switzerland, 6 -11 October.

Daloz, J-P., 2002, Elites et représentations politique: La Culture de l'échange inégal au Nigeria, Pessac, Presse Universitaire de Bordeaux, 174p.

Daloz, J-P., 2003, Political Representation and the Connection between Symbols of Distinction and Symbols of Likeness, ECPR Workshop on Political Representation, Edinburgh.

Daloz, J-P., ed., 1999, 'Le (non)-Renouvellement des Elites en Afrique Subsaharienne’, Talence: CEAN, IEP, Bordeaux.

Dunning, Thad., 2005, 'Resource Dependence, Economic Performance and Political Stability’, Journal of Conflict Resolution, Vol. 49, No. 4, 595-624.

Ehtishan, A. and Singh, R., 2003, 'Political Economy of Oil Revenue Sharing in a Developing Country: Illustrations from Nigeria’, IMF Working Paper 03/16. Ekpo, Akpan H., 2004, Inter-governmental Fiscal Relations: The Nigerian Experience, $10^{\text {th }}$ year Anniversary of the Financial and Fiscal Commission of South Africa, 10-12 August. 
Englebert, P., 2000, State Legitimacy and Development in Africa, Boulder, CO: Lynne Reinner.

Fearon, J. and Laitin, 2003, 'Ethnicity, Insurgency and Civil War', American Political Science Review, Vol. 97(1): 75-90.

Fjeldstad, Odd-Helge, 2001, 'Intergovernmental Fiscal Relations in Developing Countries: A Review of Issues’, CMI Working Papers, No. 11.

Garraud, P., 1999, 'Les Nouveaux Judes de Politique en rance', Critique Internationale, No. 3, Printemps.

Inter-Parliamentary Union, 1986, Parliaments of the World: A Comparative Reference Compendium ( $2^{\text {nd }}$ Edition), Aldershot: Gower Publishing.

Lacam, J-F., 1988, Le Politicien Investisseur: Un Modele d'interpretation de la gestion des resources politiques, Revue Française de Sciences Politiques, Vol. 38, 1 .

Mbanefoh, G. F. and Egwaikhide F., 1998, 'RevenueAllocation in Nigeria: Derivation Principle Revisited' in Amuwo Kunle et al., eds., Federalism and Political Restructuring in Nigeria, Ibadan: Spectrum Books.

Mbanefoh, G. F., 1986, 'Military Presence and the Future of Nigerian Fiscal Federalism,' Faculty Lecture Series, Faculty of Social sciences, University of Ibadan, Nigeria, No. 1.

Mbanefoh, G. F., 1989, ‘ Public Finance’ in Kayode M. O. and Y. B. Usman, eds.,

The Economy, Vol. 2, Nigeria Since Independence History Project, Heinemann Educational Books (Nigerian) Limited.

Ndubisi, O., 2004, Political Finance and Democracy in Nigeria: Prospects and Strategies for Reform, Centre for Law and Social Action (CLASDA), Lagos.

Nigeria, Federal Republic of , 1999, Constitution of the Federal Republic of Nigeria, Lagos: Federal Government Printer.

African Network for Environment and Economic Justice (2004) Oil of Poverty in Niger-Delta, ANEEJ, Port-Harcourt.

Okigbo, P., 1965, Nigerian Public Finance, Evanston: Northwestern University Press.

Olarinmoye, O. O., 2004b, Sanjay Joshi, 2002, Fractured Modernity: Making of a Middle Class In Colonial India, Oxford University Press, A Book Review Submitted to the Center for Studies in Social Sciences, Kolkata/SEPHIS International Research Fellowship Programme (IRTP 2004).

Oyediran, O. and Olagunju, O., 1984, 'The Military and the Politics of Revenue Allocation' in Oyediran, O., ed., Nigerian Government and Politics Under the Military Rule, London, Macmillan Publishers, pp. 192-211.

Robinson et al., 2005, 'Political Foundations of the Resource Curse', Manuscript, Department of Government, Harvard University, Cambridge.

Ron, J., 2005, 'Paradigm in Distress? Primary Commodities and Civil War', The Journal of Conflict Resolution, pp. 443-450.

Ross, M., 2002, ‘Booty Futures’, Working Paper, University of California, Los Angeles. 
Ross, M., 2003, 'Oil, Drugs and Diamonds: How Do Natural Resources Vary In Their Impact on Civil Wars?', in Ballentine, Karen and Sherman, Jake, eds., Beyond Greed and Grievance: The Political Economy of Armed Conflict, Boulder CO, Lynne Reinner.

Rosser, A., 2006, 'The Political Economy of the Resource Curse: A Literature Review’, IDS Working Paper, No. 268.

Sachs, J. D. and Warner, A., 1999, 'The Big Push, Natural Resource Booms and Growth', Journal of Development Economics, 59, pp.43-76.

Tamuno, Tekena T., 1998, 'Nigeria Federalism in Historical Perspective’ in Kunle Amuwo et al. Federalism and Political Restructuring in Nigeria, pp. 13-33. Uche, C.U. and Uche, O.C., 2004, 'Oil and the Politics of Revenue Allocation in Nigeria’, ASC Working Paper, No. 54, African Studies Centre, Leiden, The Netherlands.

Ugochukwu, F., 2004, 'Book Review of Elites et Représentations Politique: La Culture de l'échange Inégal au Nigeria, Passac’, Presse Universitaire de Bordeaux, Cahier d'études Africaine, Vol. 176.

Weinstein, J. M., 2005, 'Resources and the Information Problem in Rebel

Recruitment', Journal of Conflict Resolution, Vol. 49, No. 4, 595-624. 